\title{
PERKEMBANGAN ISLAM DI INDONESIA PASCA KEMERDEKAAN
}

\author{
Beti Yanuri Posha, S.Pd., M.Hum. \\ Program Studi Sejarah dan Kebudayaan Islam IAI Sultan Muhammad Syafiuddin Sambas \\ betiyanuriposha@gmail.com
}

\begin{abstract}
Abstrak
Islam merupakan agama yang meletakkan prinsip-prinsip kebenaran dan keadilan bagi setiap pemeluknya. Faktor-faktor yang mendorong umat Islam mencapai kemerdekaan yaitu faktor Ideologi, politik, ekonomi, sosial dan budaya. Di Indonesia, Islam mempunyai peranan penting di bidang pendidikan. Pendidikan Islam di Indonesia di berikan pada tiga sektor, yaitu formal, informal dan non-formal. Setelah Indonesia merdeka, masalah pendidikan agama mendapat perhatian serius dari pemerintah, baik di sekolah negeri maupun swasta, kemudian telah berdiri lembaga-lembaga pendidikan, khususnya pesantren dan surau yang telah menjadi benteng Islam yang demikian kuat berpengaruh. Oleh sebab itu, penting untuk mengkaji kembali bagaimana perkembangan Islam di Indonesia serta perkembangan lembaga-lembaga pendidikan Islam di Indonesia pasca kemerdekaan.
\end{abstract}

Kata Kunci : Perkembangan Islam, lembaga pendidikan Indonesia

\begin{abstract}
Islam is a religion that put the principles of truth and justice for all its adherents. Factors that encourage Muslims to achieve independence are factors Ideology, political, economic, social and cultural. In Indonesia, Islam has an important role in education. Islamic education in Indonesia is given in three sectors, namely formal, informal and non-formal. After Indonesian independence, the issue of religious education received serious attention from the government, both in public and private schools, and has established educational institutions, especially schools and a mosque which has become a bastion of Islam that is so strong effect. Therefore, it is important to reassess how the development of Islam in Indonesia as well as the development of Islamic education institutions in Indonesia after independence.
\end{abstract}

Keywords: Development of Islam, Education Institutions Indonesia

\section{PENDAHULUAN}

Telah tercatat dalam sejarah bahwa Islam telah berjaya dan mengalami kemajuan dalam segala bidang selama beratus-ratus tahun sehingga membuat masyarakat Islam merasa bangga dengan kejayaan yang pernah diraihnya, namun disisi lain kenyataannya umat Islam pernah mengalami kemunduran dan keterbelakangan (Harun Nasution, 1992: 12). Hal tersebut dapat dilihat setelah Nabi Muhammad saw menjadikan Islam berjaya dan diakui oleh seluruh dunia sampai sekarang ini. Oleh karena itu, di dalam diri umat Islam muncul pandangan yang menyebutkan bahwa politik dan peradaban Islam merupakan bagian yang integral dari ajaran Islam. Alasannya adalah ajaran Islam memiliki fleksibilitas dan elastisitas yang tinggi serta memiliki relevansi yang kuat dengan perkembangan umat Islam itu sendiri.

Di samping itu, salah satu bukti bahwa Islam akan tetap berjaya adalah muncul dan berkembangnya Islam di Indonesia yang telah menjadi bukti sejarah bagi bangsa Indonesia dimana peranannya sangat besar terhadap perjuangan kemerdekaan bagi bangsa Indonesia. Dengan melihat ke belakang 
sejarah masuknya Islam di Indonesia yaitu melalui berbagai macam cara dimana di antaranya adalah melalui perdagangan, perkawinan yang dimotori oleh para saudagar-saudagar Arab, pendidikan (pesantren), tasawuf, dakwah, kesenian dan budaya. Dengan kehadiran mereka maka tertarik pula kalangan putra-putri pilihan bangsa Indonesia untuk mendalami dan mempelajari Islam sampai mereka menjadi ulama besar dan aktif mendakwahkan ajaran agama Islam kepada rakyat Indonesia sehingga dari perjuangan itulah Islam sampai sekarang tumbuh dan berkembang di Indonesia.

Perjuangan Islam tersebut tidak hanya sampai sebatas itu akan tetapi perjuangan melawan penjajah pun nyawa menjadi taruhannya sehingga pada saat itu peranan Islam terhadap kemerdekaan mendapat andil yang sangat besar bagi bangsa Indonesia. Pada zaman penjajahan, manifestasi nasionalisme lebih nyata dalam melawan kolonialisme, namun nasionalisme tidak bergantung semata-mata pada kolonialisme. Kenyataannya, kesadaran nasional tetap ada meskipun tidak ada kolonialisme, atau setelah kolonialisme itu lenyap. Bahkan nasionalisme bertambah subur tanpa adanya kolonialisme. Itulah yang kita sebut nasionalisme bebas, artinya tanpa tekanan kolonialisme (Slamet Muljana, 2008: 7). Namun, pada saat kemerdekaan tercapai yaitu pada tanggal 17 Agustus 1945 timbullah pergolakan antara para kalangan yang ingin menentukan ideologi negara bangsa Indonesia. Pergolakan tersebut terbagi dalam dua kubu yaiu kalangan Muslim dan Nasionalis, salah satunya ingin menjadikan Negara Indonesia sebagai Negara Islam namun hal tersebut mendapat tantangan dari kalangan lain yang ingin menjadikan Negara Islam menjadi Negara Pancasila.

Akibat dari munculnya gejolak tersebut perkembangan Islam dari segi politik makin membesar disebabkan kekecewaan dari kalangan Islam yang ingin menjadikan Negara Indonesia menjadi Negara khilafah Islam, dan kekecewaan itu memuncak ketika dideklarasikan Negara Indonesia sebagai Negara pancasila.

\section{METODE PENELITIAN}

Penelitian ini menggunakan metode penulisan sejarah dengan melakukan tinjauan pustaka. Tahap-tahap penelitian ini adalah mengumpulkan data (heuristik) yang sekiranya akan menunjang dalam penelitian tentang perkembangan islam pasca kemerdekaan. Tahap berikutnya adalah kritik sumber memilah data yang memang meiliki tingkat otentisitas dan kredibilitas yang sesuai dengan penelitian. Interpretasi adalah penafsiran data berdasarkan data yang telah tersedia. Tahap terakhir adalah penulisan hasil penelitian. 


\section{PEMBAHASAN}

Perkembangan Islam Indonesia Pasca Kemerdekaan

Sejarah kehidupan Islam di Indonesia telah diakui sebagai kekuatan cultural, tetapi Islam dicegah untuk merumuskan bangsa Indonesia menurut versi Islam. Sebagai kekuatan moral dan budaya, Islam diakui keberadaannya, tetapi tidak pada kekuatan politik secara riil. Perkembangan selanjutnya pada masa Orde Lama, Islam telah diberi tempat tertentu dalam konfigurasi yang paradoks, terutama dalam dunia politik. Sedangkan Orde Baru, tampaknya Islam diakui sebatas sebagai landasan moral bagi pembangunan bangsa dan Negara.

Pendiskriminasian Islam tersebut memang sudah diawali pada saat wajah (ideologi) Indonesia akan ditentukan sehingga muncullah berbagai gerakangerakan dan pertentangan-pertentang Islam anti pemerintah akibat kekecewaan terhadap pembentukan Negara Pancasila sebagai dasar Negara Indonesia.

\section{Gerakan DI/TII di Indonesia}

Negara Islam Indonesia (NII) yang kemunculannya oleh berbagai pihak dituding sebagai akibat dari merasa sakit hatinya kalangan Islam, dan bersifat spontanitas, lahir pada saat terjadi vacum of power di Republik Indonesia (RI). Sejak tahun 1926, telah berkumpul para ulama di Arab dari berbagai belahan dunia termasuk H.O.S Tjokroaminoto guna membahas rekonstruksi khilafah
Islam yang runtuh pada tahun 1924 sayangnya, isyuro para ulama tersebut tidak membuahkan hasil dan tidak berkelanjutan (Ira M. Lapidus, 2000: 340). Oleh karena itu, muncullah gerakan yang disebut Darul Islam. Darul Islam secara harfiah berasal dari bahasa Arab dan AlIslam yang berarti rumah atau keluarga Islam, dunia atau wilayah Islam. Pengertian secara istilah Darul Islam di Indonesia digunakan untuk menyatakan gerakan-gerakan sesudah tahun 1945 yang berusaha dengan kekerasan untuk merealisasikan cita-cita Negara Islam (C.Van Dijk, 1983: 1).

Gerakan kekerasan yang bernada Islam ini terjadi di berbagai daerah di Indonesia di antaranya Jawa Barat pada 1949-1962, Jawa Tengah pada 1965, Sulawesi berakhir 1965, di Kalimantan berakhir 1963 dan di Aceh pada 1953 yang berakhir dengan kompromi pada tahun 1957. Gerakan-gerakan Islam tersebut mendapat perlawanan keras dari tentara republik Indonesia karena mereka dianggap tidak patuh dan tunduk pada pemerintah serta melakukan pemberontakan dimana-dimana di antaranya adalah Gerakan DI/TII Jawa Barat yang dipimpin oleh Sekarmaji Kartosuwiryo, Gerakan DI/TII Jawa Tengah yang dipimpin oleh Amir Fattah, Pemberontakan di Sulawesi Selatan yang dipimpin oleh Kahar Muzakkar, Pemberontakan di Kalimantan Selatan yang dipimpin Ibnu Hadjar dan Pemberontakan di Aceh yang dipimpin 
Daud Beureuh (Ajid Thohir, 2004: 305311).

Pergumulan Islam, Sosialisme, Nasionalisme dan Komunisme

Setelah Kemerdekaan Indonesia tercapai, mulailah terjadi konflik tentang perbedaan dan persaingan untuk memperoleh kemerdekaan. Beberapa konflik yang terjadi pada waktu itu umumnya merupakan gerakan belum membahayakan dan bermunculan partaipartai antara lain:

Pertentangan diantara partai-partai (1950-1955)

Pertarungan pada fase ini lebih tajam lagi ditandai dengan perpecahan diantara partai karena ketidakpuasan dan perbedaan pemahaman. Yaitu sejumlah anggota Masyumi yang dipimpin Wondoami Seno dan Aruzi Kartawinata memisahkan diri dengan mendirikan partai Serikat Islam Indonesia (PSII) yang lama agar dapat duduk dalam kabinet, pecahnya Partai Masyumi yang sosialis agama dengan kelompok konservatif, pada bulan April 1952 Nahdhatul Ulama (NU) keluar dari Masyumi sebagai partai politik yang dasarnya perebutan jabatan kementrian agama di kabinet dan bulan April 1955 PKI membuat persetujuan dengan PSII sebagai pencegahan pandangan masyarakat bahwa PKI anti agama (BJ. Boland, 1985: 46).

Pertentangan Ideologi

Pertentangan ideologi ini menyebabkan terbentuknya dua blok yaitu tentang perumusan dasar Negara antara Negara yang berdasarkan Pancasila dan Islam. Jika dilihat keadaan umat Islam pada saat itu masih sangat terpuruk karena persatuan mereka terpecah sehingga cita-cita untuk mendirikan Negara Islam sebagai tujuan utama terkendala akibat pergolakan politik yang tidak dapat dibendung lagi oleh tokohtokoh Islam. Namun kenyataannya sekalipun partai-partai Islam berbeda paham, tetapi pada saat menghadapi partai-partai anti Islam mereka bersama membentuk front demi tercapainya tujuan utama yaitu Negara Islam.

Perkembangan Lembaga Pendidikan Islam Indonesia Pasca Kemerdekaan

Pemikiran pendidikan Islam periode Indonesia merdeka diwarnai dengan model pendidikan dualistis: pertama, sistem pendidikan dan pengajaran pada sekolah-sekolah umum yang sekuler, tidak mengenal ajaran agama, yang merupakan warisan dari pemerintah kolonial Belanda. Kedua, sistem pendidikan dan pengajaran Islam yang tumbuh dan berkembang di kalangan masyarakat Islam, baik yang bercorak isolatif-tradisional maupun yang bercorak sintesis dengan berbagai variasi pola pendidikannya (Wirjosukarto, 1985: 82). Kedua sistem pendidikan tersebut sering dianggap saling bertentangan serta tumbuh dan berkembang secara terpisah. Sistem pendidikan dan pengajaran yang pertama, pada mulanya hanya 
menjangkau dan dinikmati oleh sebagian kalangan masyarakat, terutama kalangan atas saja. Sedangkan yang kedua (sistem pendidikan dan pengajaran Islam), tumbuh dan berkembang secara mandiri di kalangan rakyat dan berakar dalam masyarakat.

Sistem pendidikan Islam yang ada dan telah berkembang pada masa itu, sebagai salah satu bentuk dan usaha pelaksanaan syariat Islam, mendapatkan kesempatan dan jaminan untuk tetap berlangsung dan berkembang, serta mendapatkan perhatian dan bantuan dari pemerintah. Menurut ajaran Islam, pendidikan merupakan bagian hakiki dari tugas pengabdian (ibadah) dan kekhalifahan manusia terhadap Tuhan yang harus dilaksanakan dengan penuh tanggung jawab (Susanto, 2009: 18-19). Pendidikan Islam di Indonesia pasca penjajahan (zaman kemerdekaan) dapat dibagi menjadi dua, yaitu:

Pendidikan Islam sebagai lembaga

Pendidikan Islam sebagai lembaga tumbuh dan berkembang pada masa kemerdekaan dengan pesat, seperti; pesantren, sekolah, madrasah dan perguruan tinggi. Pesantren yang sudah tumbuh ratusan tahun, pada era kemerdekaan mendapat tempat untuk berkembang. Sedangkan sekolah ini terbagi menjadi dua, yaitu sekolah negeri dan swasta. Sekolah swasta ini juga terbagi menjadi dua yaitu sekolah Islam dan sekolah non Islam. Kemudian madrasah ini diberlakukan sejak SK 3
Menteri tahun 1975 yang berlangsung sampai 1990. SK 3 Menteri itu adalah Menteri Agama, MENDIKBUD dan menteri Dalam Negeri, yang isinya adalah sekolah madrasah memiliki persamaan dan kedudukan yang setara dengan sekolah, sehingga disebut madrasah itu adalah sekolah yang berciri khas Islam.

Pendidikan Islam sebagai mata Pelajaran Pendidikan Islam secara formal telah dimasukkan ke sekolah-sekolah sejak tahun 1946, sejak dimulainya pelajaran agama di sekolah-sekolah umum. Terakhir tercantum dengan jelas dalam UUD No. 20 Tahun 2003 tentang Sistem Pendidikan Nasional. Dengan undang-undang tersebut, posisi pendidikan Islam sebagai subsistem pendidikan nasional semakin mantap, baik pada lembaga pendidikan umum maupun keagamaan (Azra, 2002: 57). Berdasarkan dari undang-undang tersebut bahwa perhatian pemerintah terhadap pendidikan Islam sudah baik di mana lembaga-lembaga tersebut sudah disetarakan dengan sekolah umum sehingga tidak lagi terdapat perbedaan antara satu lembaga dengan lembaga pendidikan lainnya.

Salah satu bukti bahwa Pendidikan Islam sudah mendapat perhatian pemerintah, dapat dilihat dari pengaruh ide-ide pembaharuan yang berkembang di dunia Islam dan kebangkitan bangsa Indonesia, sedikit demi sedikit pelajaran umum masuk ke dalam kurikulum madrasah. Buku-buku pelajaran agama 
mulai disusun khusus sesuai dengan tingkatan madrasah, sebagai halnya bukubuku pengetahuan umum yang belaku di sekolah-sekolah umum. Bahkan kemudian timbullah madrasah-madrasah yang mengikuti sistem perjenjangan dalam bentuk sekolah-sekolah modern, seperti Madrasah Ibtidaiyah untuk tingkat dasar, Madrasah Tsanawiyah untuk tingkat menengah pertama, dan adapula Kuliah Muallimin (pendidikan guru) yang disebut normal Islam (Mahmud Yunus, 1996: 102). Pada tahap selanjutnya penyesuaian tersebut semakin meningkat dan terpadu dengan baik sehingga sukar untuk dipisahkan dan dibedakan antara keduanya, kecuali madrasah yang langsung ditulis predikat Islamiyah. Kurikulum madrasah atau sekolah-sekolah agama, mempertahankan agama sebagai mata pelajaran pokok, walaupun dengan persentase yang berbeda. Pada waktu pemerintahan $\mathrm{RI}$ dalam hal ini oleh Kementerian Agama mulai mengadakan pembinaan dan pengembangan terhadap sistem pendidikan madrasah. Melalui Kementerian Agama, madrasah perlu menentukan kriteria madrasah. Kriteria yang ditetapkan oleh Menteri Agama untuk madrasah-madrasah yang berada di dalam wewenangnya adalah harus memberikan pelajaran agama sebagai mata pelajaran pokok, paling sedikit enam jam seminggu.

Uraian-uraian di atas, dapat disimpulkan bahwa pada dasarnya sistem pendidikan dan pengajaran di madrasah merupakan perpaduan antara sistem yang berlaku di pondok pesantren dengan sistem yang berlaku di sekolah-sekolah modern. Di samping itu, dalam upaya pemerintah untuk menyediakan guru-guru agama untuk sekolah dan guru-guru umum serta lembaga pendidikan lainnya pada tahun 1951 Kementerian Agama mendirikan Sekolah Guru Agama Islam (SGAI) dan sekolah Guru dan Hakim Agama Islam (SGHAI) di beberapa tempat. Berdirinya kedua jenis sekolah guru tersebut banyak manfaatnya bagi perkembangan dan pembinaan madrasah, karena kedua jenis sekolah guru ini, memberikan kesempatan bagi para alumni madrasah dengan persyaratan tertentu untuk memasukinya. Hal tersebut telah mendorong penyelenggaraan madrasah untuk memenuhi persyaratan yang ditetapkan pemerintah. Pada alumni kedua jenis sekolah guru agama tersebut, diperbantukan pada madrasah-madrasah guna mempercepat proses pembinaan dan perkembangannya, menuju kepada pengintegrasian ke dalam sistem pendidikan nasional (Zuhairini, 1986: 78).

Kedua jenis sekolah guru itu, kemudian namanya diubah menjadi PGA (Pendidikan Guru Agama) dan SGHA (Sekolah Guru dan Hakim Agama). PGA menyediakan calon guru agama untuk sekolah dasar dan madrasah tingkat Ibtidaiyah, sedangkan SGHA menyediakan calon-calon guru agama untuk tingkat sekolah menengah baik sekolah agama 
maupun sekolah umum, dan hakim pada Pengadilan Agama. Pada tahun 1957 SGHA disebut sebagai PGA dan untuk keperluan tenaga pendidikan hakim agama didirikan PHIN (Pendidikan Hakim Negeri). Pada masa itu banyak madrasah tingkat Tsanawiyah dan Aliyah berubah menjadi PGA. Dengan demikian, disamping PGA pertama (4 tahun), 9 buah PGA atas (2 tahun) dan 1 buah PHIN (3 tahun), (Mahmud Yunus, 1996: 393).

Upaya pembinaan madrasah, menuju kesatuan sistem pendidikan nasional, semakin ditingkatkan. Usaha tersebut tidak hanya merupakan tugas dan wewenang Departemen Agama saja, tetapi merupakan tugas dan wewenang pemerintah secara keseluruhan bersama masyarakat. Pada tahun 1975, dikeluarkan Surat Keputusan Bersama (SKB) 3 Menteri antara Menteri Dalam Negeri, Menteri Agama dan Menteri Pendidikan dan Kebudayaan, tentang peningkatan mutu pendidikan pada madrasah. Hal ini dilatar belakangi bahwa siswa-siswa madrasah sebagaimana halnya tiap-tiap warga negara Indonesia berhak memperoleh kesempatan yang sama untuk memperoleh pekerjaan dan penghidupan yang layak bagi kemanusiaan dan pengajaran yang sama, sehingga lulusan madrasah, yang menghendaki melanjutkan atau pindah ke sekolah-sekolah umum dari tingkat sekolah dasar sampai perguruan tinggi. Dalam rangka merealisasikan SKB 3 menteri tersebut, maka pada tahun 1976
Departemen Agama mengeluarkan kurikulum sebagai standar untuk dijadikan acuan oleh madrasah, baik untuk MI, MTs, maupun Madrasah Aliyah.

Berdasarkan

uraian-uraian tersebut, bahwa pembinaan dan pengembangan madrasah tetap dilaksanakan semenjak munculnya istilah madrasah sampai lahirnya SKB 3 Menteri, di mana madrasah dipersamakan dengan sekolah umum, yang dalam hal ini adalah sekolah negeri umum yang berada di bawah naungan Departemen Pendidikan dan Kebudayaan yang sederajat. Dan demikian jelasnya bahwa pemerintah tetap memperhatikan pertumbuhan dan perkembangan madrasah di Indonesia.

\section{SIMPULAN}

Peradaban Islam di Indonesia pasca kemerdekaan telah mengalami keguncangan di mana perseteruan antara kelompok nasionalis dan kelompok Islam dan kelompok lainnya masing-masing berpegang teguh pada misi mereka untuk menjadikan negara Indonesia menjadi Negara Islam Negara Pancasila. Dengan timbulnya masalah ini, maka timbullah pergerakan-pergerakan, partai-partai dan pemberontakan yang dilakukan oleh kelompok Islam. Hal tersebut dilakukan oleh Islam karena mereka kecewa dengan hasil keputusan presiden yang menjadikan dasar Negara Indonesia sebagai Negara Pancasila.

Perkembangan lembaga-lembaga Pendidikan Islam di Indonesia pasca 
kemerdekaan cukup berkembang pesat karena pemerintah memberikan peluang besar dengan melakukan penyetaraan dengan sekolah umum sehingga sekolah Islam tidak mengalami ketertinggalan. Serta dengan diberlakukannya Undangundang RI Nomor 20 Tahun 2003 tentang Sistem Pendidikan Nasional, secara konseptual undang-undang tersebut memberikan arah baru dalam mengembangkan dan memberdayakan pendidikan Islam di Indonesia mencapai kemajuan yang gemilang.

\section{DAFTAR PUSTAKA}

Azra, Azyumardi. 2002. Pendidikan Islam: Tradisi dan Modernisasi Menuju Millenium Baru. Jakarta: Logos.

Boland B.j. 1985. Pergumulan Islam di Indonesia 1945-1970. Jakarta: Grafiti Pers.

Dijk, C Van. 1983. Darul Islam, Sebuah Pemberontakan. Jakarta: Grafiti Pers.

Lapidus, Ira M. 2000. Sejarah Sosial ummat Islam. Cet. II; Jakarta: PT. Raja grafindo Persada.

Nasution, Harun. 1992. Ensiklopedi Islam. Jakarta: Anda Utama.

Susanto, A. 2009. Pemikiran Pendidikan Islam. Jakarta: Amzah.

Thohir, Ajid. 2004. Perkembangan Peradaban di Kawasan Dunia Islam. Cet. I; Jakarta: PT. Raja Grafindo Persada.

Wirjosukarto, Amir Hamzah. 1985. Pembaharuan Pendidikan dan Pengajaran Islam. Jember: Muria Offset.
Yunus, Mahmud. 1996. Sejarah Pendidikan Islam di Indonesia. Jakarta: Hidakarya Agung.

Zuhairini. 1986. Sejarah Pendidikan Islam di Indonesia. Jakarta: Proyek Pembinaan Prasarana dan Sarana Perguruan Tinggi Agama/IAIN Jakarta. 